\title{
The Tatars and the Term Zakhvatchiki in Soviet Historiography
}

\author{
Ch. J. Halperin
}

For citation: Halperin Ch. J. The Tatars and the Term Zakhvatchiki in Soviet Historiography. Vestnik of Saint Petersburg University. History, 2019, vol. 64, iss. 4, pp. 1429-1439. https://doi.org/10.21638/11701/spbu02.2019.417

Soviet historiography categorized the Mongols in general and the Tatars of the Golden Horde in particular as zakhvatchiki. Reading Soviet historiography on Rus'-Tatar relations induces the thought that the use of the word zakhvatchiki had an anti-nomadic coloration, that it was a negative denomination just for nomadic tribes who were a frequent occurrence in Russian history. Post-Soviet Russian historiography has not completely overcome the heritage of using this demeaning term to dismiss the Tatars as barbarian parasites. However, examination of an artifact of Soviet historiography, a multi-volume collective work on historiography in the territory that came to comprise the Soviet Union, disproves any suspicion that application of this word to the Tatars derives from anti-nomad prejudice. To appreciate this evidence properly it must be cited in extenso. To illustrate the dispersion of such references, the author cites them individually by first surveying appearances of the term volume by volume. In each case, he enumerates the name(s) of the historian(s), their subject, where appropriate - the chronology, who the zakhvatchiki were, and who their victims were. He interprets references to zakhvatnicheskie policies as markers of who was a zakhvatchik. After that he provides aggregate analysis of this evidence. Soviet historians applied the word to all periods of world, not just Russian, history, to anyone who qualified as a villain in Soviet Marxist historiography, most often, unsurprisingly, to imperialists. The author examines the meaning of the word separately. It is difficult to convey the richness of its connotations by a single word in English. Consequently, the word itself has no anti-nomad connotations; in effect, it can be reduced to a cliche moniker for all "bad guys." It is still anachronistic because no medieval Rus' source ever called the Tatars "zakhvatchiki." It should be avoided in scholarship.

Keywords: Soviet historiography, zakhvatchik, Tatars, Golden Horde.

\section{Татары и термин захватчики в советской историографии}

\section{Ч. Дж. Гальперин}

Для цитирования: Halperin Ch.J. The Tatars and the Term Zakhvatchiki in Soviet Historiography // Вестник Санкт-Петербургского университета. История. 2019. Т.64. Вып. 4. С.1429-1439. https://doi.org/10.21638/11701/spbu02.2019.417

Charles J. Halperin - PhD, Research Associate Russian and East European Institute Indiana University, Bloomington, Indiana, USA, 47408-3574; chalperi@indiana.edu

Чарльз Дж. Гальперин - PhD, Институт России и Восточной Европы Университета Индианы, Блумингтон, Индиана, США, 47408-3574; chalperi@indiana.edu

(c) Санкт-Петербургский государственный университет, 2019 
Советская историография определяла монголов вообще и татар Золотой Орды в частности как «захватчиков». Изучение работ советских историков создает впечатление, что этот термин имеет антикочевническую окраску, дает негативное определение именно монголам и другим кочевникам, приход которых был столь частым явлением в истории России. Постсоветская российская историография не полностью преодолела советское наследие: уничижительный термин используется для того, чтобы отмахнуться от татар как от варварских паразитов. Однако изучение такого артефакта советской историографии, многотомного коллективного труда по историографии сформировавшейся практически на всей территории, которую включал в себя Советский Союз, опровергает любые подозрения, что применение этого слова к татарам происходит от предубеждения по отношению к кочевникам. Чтобы понять это, автору статьи пришлось внимательно рассмотреть все тома и разделы «Очерков истории исторической науки». Он фиксирует все случаи появления этого термина, имена историков, вводивших его в обиход. Упоминания «захватнической политики» рассматривается как своего рода маркер «захватничества» и далее анализируется сама историческая ситуация. Советские историки применяли это слово ко всем периодам мировой истории, а не только к русской, к любому, кто считался злодеем в советской марксистской историографии, чаще всего, что неудивительно, к империалистам. Отдельно в работе рассматривается значение слова «захватчики». Одним словом передать все богатство эмоциональной коннотации этого выражения очень трудно. Во всяком случае, само слово не имеет антикочевых коннотаций; в сущности, его можно превратить в прозвище, клише для всех «плохих парней» (bad guys). Это все еще анахронизм, потому что ни один источник средневековой Руси никогда не называл татар «захватчиками». В научной традиции от этого понятия стоит отказаться.

Ключевые слова: советская историография, захватчик, татары, Золотая орда.

\section{Introduction}

Specialists in the history of the Golden Horde and Rus'-Tatar relations continue to descry the "traditional negative stereotypes," as Vadim Trepalov phrased it, of the Tatars in Russian historiography, which are accompanied by the view that the Golden Horde survived solely on the basis of coercion. Rafael Khakimov called attention to the "barbaric images" of the Tatars and the depiction of the Golden Horde as a "source of savagery, humiliation for Russians and a threat to Europe as a whole"1. The word zakhvatchik, ubiquitous in Soviet historiography, encapsulates this hostile point of view toward the Tatars $^{2}$. Some post-Soviet Russian historiography has overcome this one-sided approach to Rus'-Tatar relations. For example, in most of his works Iurii Seleznev either does not use the term or uses it extremely sparingly. On the other hand, it remains a commonplace in other recent scholarship ${ }^{3}$.

1 Trepavlov V. Introduction // The Golden Horde in World History. Kazan', 2017. P. 11; Khakimov R. Foreword // Ibid. P. 3 / ed. by M. Gibatdinov. Kazan', 2017.

2 Because the translation of this word is problematic, for the moment I will use the Russian word. Possible translations will be discussed below.

3 Seleznev Yu.V. Russko-ordynskie konflikty XIII-XV vekov. Moscow, 2010. P.6; Amel'kin A.O., Seleznev Iu. V. Kulikovskaia bitva v svidetel'stvakh sovremennikov i pamiati potomkov. Moscow, 2011. P. 146, 331. - The other three books by Seleznev reviewed in: Halperin Ch. J. Iu. V. Seleznev's Contribution to the Study of the Juchid ulus // Zolotoordynskoe obozrenie. 2014. Vol.2, no. 4. P.74-94 did not employ the term even once, nor does his most recent monograph; Seleznev Iu. V. Kartiny ordynskogo iga. Voronezh, 2017, 
It would be easy, actually too easy, to assign usage of the word to anti-nomad prejudice, as this author long suspected, but that would be misleading. Close examination of the appearance of the term in a collective multi-volume survey of historiography on the territory of the USSR clearly demonstrates that the word was used generically for all peoples, classes, and governments that were villains in Soviet Marxist history. As such, it should be treated as a little more than an anachronistic generic term of opprobrium devoid of historical content and context.

\section{Ocherki istorii istoricheskoi nauki v SSSR}

Five volumes of Ocherki istorii istoricheskoi nauki $v$ SSSR appeared in print between 1955 and $1985^{4}$. The changing vicissitudes of Soviet historiography, specifically the ups and downs of de-Stalinization, strongly affected its presentation of Russian history, but it was the fall of the Soviet Union that terminated the project. Three planned additional volumes remained unwritten. The project encompassed the development of historiography in all areas that were part of the USSR after World War II but about the history of all regions of the world during ancient, medieval, early modern and modern history. Naturally the most attention was devoted to Russia and the territories of the Russian Empire and the USSR, but the coverage of all of Eurasia was extensive. The scale of the project can be indicated by two statistics: overall 21 historians served as editors of one or more volumes, and 133 historians contributed to one or more volumes. Ocherki istorii istoricheskoi nauki $v$ SSSR is virtually an official synthesis of Soviet historiography from the death of Stalin to the eve of perestroika. How the historians who authored chapters and sub-chapters applied the word zakhvatchik demonstrates comprehensively how the term was perceived by Soviet historiography.

To appreciate this evidence properly, it must be cited in extenso. To illustrate the dispersion of such references, it is necessary to cite them individually by first surveying appearances of the term volume by volume. In each case, I will enumerate the name(s) of the historian(s), their subject, where appropriate the chronology, who the zakhvatchiki were, and who their victims were. I have interpreted references to zakhvatnicheskie policies as markers of who was a zakhvatchik. After that I will provide aggregate analysis of this evidence.

unlike Rudakov V.N. Mongolo-Tatary glazami drevnerusskikh knizhnikov serediny XIII-XV vv. Moscow, 2009, which uses it frequently, for example. P. 9, 174, which is otherwise a first-rate piece of scholarship.

${ }^{4}$ Ocherki istorii istoricheskoi nauki v SSSR. Vol. 1 / eds M. N. Tikhomirov, M. A. Alpatov, A. L. Sidorov. Moscow, 1955; Ibid., Vol.2 / eds M.V.Nechkina, M.N.Tikhomirov, S.M.Dubrovskii, M.A.Alpatov, G. V. Veber, A. M. Stanislavskaia. Moscow, 1960; Ibid., Vol. 3 / eds M. V. Nechkina, M. A. Alpatov, G. V. Veber, E. N. Gorodetskii, S. D. Dubrovskii, A.M. Stanislavskaia. Moscow, 1963; Ibid., Vol. 4 / eds M. V.Nechkina, G. D. Alekseeva, M. A. Alpatov, I. B. Berkhina, G. V. Veber, G. N. Golikov, E. N. Gorodetskii, V. A. Dunaevskii, A. M. Stanislavskaia, L. V.Cherepnin. Moscow, 1966; Ibid, Vol.5 / eds M.V.Nechkina, M.A.Alpatov, I.B.Berkhin, V.I. Buganov, G. V.Veber, E. N. Gorodetskii, V.A. Dunaevskii, L. V. Ivanova, T. A. Ignatenko, V.P. Naumov, V. N. Nikiforov, K. N. Tarnovskii, L. V. Cherepnin, V. P. Sherstobitov. Moscow, 1985 [Cherepnin died in 1977, so he must have made his editorial contribution long before Volume Five appeared.] For convenience references to these volumes will be given in parentheses in the text by volume number and pages. 


\section{Who Was a zakhvatchik?}

In Volume One writing about the Ancient Near East an anonymous contributor noted that the ancestors of the Azerbaijanis were threatened by Assyrian zakhvatchiki ${ }^{5}$. The later sub-chapter on Azerbaijan by a collective of historians including A. A. Alizade notes the wars between the Azerbaijanis and Persian, Arab, and Ottoman zakhvatchiki ${ }^{6}$. R.N.Nabiev writing about Uzbekistan, labels the campaigns of Babur into India as zakhvatnicheskie ${ }^{7}$. V.E. Elleritskii denigrates Napoleon and his invading army as zakhvatchiki ${ }^{8}$. Russians and Ukrainians, according to L. A. Kovalenko on the history of Ukraine, defeated the Swedish zakhvatchiki at Poltava9. K. V. Laigna calls the East German barons who invaded Estonia zakhvatchiki ${ }^{10}$.

In Volume Two, contributors applied the word zakhvatchiki to a wide range of objects. N.A.Smirnov praised V.D.Smirnov's classic study of the Crimean Khanate for demonstrating the Crimea's zakhvatnicheskaia policy toward Russia, Poland, Ukraine, and the North Caucasus, which derives from its slave-raiding ${ }^{11}$. T. Ia. Draudin mentions the German zakhvatchiki who assaulted the Latvian people (narod), which took the form of conquest ${ }^{12}$. Ia.S. Grosul and N. A. Mokhov unmask the zakhvatnicheskie ambitions of the Romanian boyars and bourgeoisie to take Bessarabia back from the Russian Empire in the early nineteenth century ${ }^{13}$. On Azerbaijan I.M. Gasanov and A.N. Guliev give the despotic Iranian shah Abbas I credit for expelling the Uzbek and Ottoman zakhvatchiki from Azerbaijan but criticize Iranian shah Muxammed-shah as a zakhvatchik for invading $\mathrm{Karaba}^{14}$. A. I. Akatova cites approvingly a Turkmen poem extolling Sunni Turkmen for defeating the Iranian Shiite zakhvatchiki who had invaded their homeland and deplores the zakhvatnicheskie activities of the English in Central Asia ${ }^{15}$. Finally, although Kh. G. Gimadi did not use the word zakhvatchiki in a sub-chapter on Tataria, he vilified (Tatar) bourgeois nationalistic historiography for turning Muslim khans and Idigei (who was not a khan. $-\mathrm{CJH}$ ) into heroes for conducting acts of banditry ${ }^{16}$, implicitly zakhvatnicheskie.

In Volume Three, G.D. Alekseeva and E. N. Gorodetskii, discussing Bolshevik historical literature, criticized I.I.Skvortsev-Stepanov for neglecting Lenin's description of imperialism as the next stage of capitalism by describing imperialism no more than a "protectionist, zakhvatnicheskaia, colonial policy"17. The inextricable link of imperialism to zakhvatnichestvo stands out in Volume Three. The same co-authors refer to the "an-

${ }^{5}$ Istoricheskie znaniia v rabovladel'cheskikh gosudarstvakh Prichernomor'ia, Zakavkaz'ia i Srednei Azii // Ocherki istorii istoricheskoi nauki v SSSR, Vol. 1. P. 22 .

${ }^{6}$ Istoriografiia Azerbaidzhana // Ibid. P. 148, 152.

7 Nabiev R. N. Istoriografiia Uzbekistana // Ibid. P. 163.

8 Illeritskii V.E.: 1) Osnovnye cherty razvitiia istoricheskikh znanii 30-50-kh godov XIX v. // Ibid. P. 325; 2) Istoricheskie vzgliady A. I. Gertsena // Ibid. P. 407. Seleznev Yu. V., Amel'kin A. O. Kulikovskaia bitva v svidetel'stvakh sovremennikov i pamiati potomkov. P.331. - labels Mamai and Napoleon "zakhvatchiki."

9 Kovalenko L. A. Istoriografiia Ukrainy // Ocherki istorii istoricheskoi nauki v SSSR. Vol. 1. P. 601.

${ }^{10}$ Laigna K. Istoriografiia Estonii // Ibid. P. 625.

11 Smirnov N. A. Izuchenie istorii stran Blizhnego i Srednego Vostoka // Ibid. Vol. 2. P. 530.

12 Draudin T. Ya. Istoriografiia Latvii // Ibid. P. 741.

13 Grosul Ia. S., Mokhov N. A. Istoriografiia Moldavii // Ibid. P. 760.

14 Guliev A. N., Gasanov I. M., Strigunov I. V. Istoriografiia Azerbaidzhana // Ibid. P. 774, 777.

15 Akatova A. I. Istoriografiia Turkmenistana // Ibid. P. 801, 806.

16 Gimadi Kh. K. Istoriografiia Tatarii // Ibid. P. 821-823.

17 Alekseeva G.D., Gorodetskii E. N. Izuchenie istorii gosudarstva i ekonomicheskogo razvitiia Rossii // Ibid. Vol.3. P. 195. 
ti-popular, zakhvatnicheskii character of contemporary wars," fought implicitly by imperialists $^{18}$. M. A. Alpatov writes that the medievalist D. N. Egorov used a conception of global history in which nothing changes to defend zakhvatnicheskaia imperialist policies because they always existed ${ }^{19}$. S. A. Nikitin on Slavic Studies alludes to the zakhvatnicheskie striving of the Russians bourgeoisie and the zakhvatnicheskie plans of the tsarist government in the Balkans ${ }^{20}$. Smirnov on the history of the Near and Middle East identifies the zakhvatnicheskaia policy of England toward Afghanistan ${ }^{21}$ and the zakhvatnicheskaia policy of English imperialism toward Egypt ${ }^{22}$. Discussing Estonia during the period of capitalism, E. A. Iansen referred to Western (German) zakhvatchiki ${ }^{23}$. Guliev, Gasanov, and I. V.Strigunov deride bourgeois nationalists in Azerbaijan for remaining silent on the resistance of the peoples of the Caucasus against foreign zakhvatchiki $i^{24}$ and refer to the zakhvatnicheskie aspirations of the clique of the Iranian shah and English and French colonizers ${ }^{25}$. Concerning Uzbekistan V. Ia. Nepomnin refers to the zakhvatnicheskie efforts of the tsarist regime in Central Asia ${ }^{26}$, and Akatova and O. L. Kuliev adduce the zakhvatnicheskaia policy of Russia toward Turkmenistan ${ }^{27}$.

Zakhvatnichestvo figures prominently and frequently in Volume Four. A. A.Zimin and A. A. Preobrazhenskii in their survey of publications on "feudal" Russia did not fail to mention foreign interventionist (zakhvatchiki) during the Time of Troubles ${ }^{28}$. They criticized works on seventeenth- and eighteenth-century Russian relations with Georgia, Central Asia, and the North Caucasus for omitting the help the friendly Russian people gave the nationalities of those places in fighting foreign zakhvatchiki $i^{29}$. In discussing foreign policy, Fadeev wrote that Engels had delineated the zakhvatnicheskaia foreign policy of Tsarism. Fadeev also referred to tsarism's zakhvatnicheskie aspirations. On the other hand, he faulted Pokrovskii for implying that only Russian Tsarism had zakhvatnicheskie foreign policy goals ${ }^{30}$. L.V. Danilova, introducing the chapter on oriental studies, refers to the zakhvatnicheskaia policy of the English in India ${ }^{31}$. Discussing Turkey, Smirnov criticized Russia's zakhvatnicheskaia policy at the end of the nineteenth century and the zakhvatnicheskie plans of imperialist countries toward the Straits ${ }^{32}$. R. T. Akhramovich criticized the zakhvatnicheskie policies of the imperialist states toward Afghanistan ${ }^{33}$. L. B. Alaev likewise criticized the English zakhvatnicheskaia policy toward India ${ }^{34}$. V. I. Shipaev referred

18 Alekseeva G.D., Gorodetskii E. N. Voprosy vseobshchei istorii v bol'shevistskoi literature // Ocherki istorii istoricheskoi nauki v SSSR. P. 209.

19 Alpatov M. A. Russkaia medievistika // Ibid. P. 437.

${ }^{20}$ Nikitin S. A. Slavianovedenie // Ibid. P. 498, 499.

${ }^{21}$ Smirnov N. A. Izuchenie istirii stran Blizhnego i Srednego Vostoka // Ibid. P. 542.

22 Ibid. P. 546.

23 Iansen E. A. Istoriografiia (Estonii) v period kapitalizma // Ibid. P. 684.

${ }^{24}$ Guliev A. N., Gasanov I. M., Strigunov I. V. Istoriografiia Azerbaidzhana // Ibid. P. 721.

25 Ibid. P.722.

${ }^{26}$ Nepomnin V. Ia. Istoriografiia Uzbekistana // Ibid. P. 733.

27 Akatova A.I., Kuliev O. K. Istoriografiia Turkmenistana // Ibid. P. 739.

28 Zimin A. A., Preobrazhenskii A. A. Izuchenie istorii feodalizma v Rossii // Ibid. Vol.4. P. 297.

29 Ibid. P. 306.

${ }^{30}$ Fadeev A. V. Vneshniaia politika Rossii v osveshchenii sovetskikh istorikov // Ibid. P.427, 430, 434-435.

31 Danilova L. V. Vvedenie // Ibid. P.737.

32 Smirnov N. A. Turtsiia // Ibid. P.748.

33 Akhramovich R. T. Afganistan // Ibid. P. 463-464.

34 Alaev L. B. Indiia // Ibid. P. 777. 
to the zakhvatnicheskie motives of imperialist powers toward Korea, specifically Japan and the US. He accused American missionaries in Korea of being tools of US imperialism ${ }^{35}$. V.N. Nikiforov called attention to the aggressive zakhvatnicheskie imperialist plans of the US towards China beginning in the eighteenth century that failed because they were too ambitious $^{36}$. G. A. Podpalova referred to the zakhvatnicheskaia policy of Japanese ruling circles $^{37}$.

In Volume Five, L.V.Cherepnin, analyzing the basic stages of the growth of Soviet historiography, wrote that although the Russian annexation of Kazakhstan was bad, nevertheless, it enabled the Russian people to join the Kazakhs in fighting foreign zakhvatchiki and their own feudal lords ${ }^{38}$. L. V. Ivanova, discussing the Institute of Marxism-Leninism, called the World War II German-Fascists zakhvatchiki $i^{39}$, as did A.I. Alatortseva discussing periodicals, but she also referred to the zakhvatnicheskie plans for the Soviet Republic of the Kaiser's Germany during $1917-1918^{40}$. V. A. Emets on Russian foreign policy during the period of imperialism similarly criticizes German zakhvatnichekie plans for Russia and Eastern Europe during World War $\mathrm{I}^{41}$. On the history of the Communist Party, N.N. Maslov refers to the German-Fascist zakhvatchiki of World War II ${ }^{42}$. Discussing agrarian history, A. I. Danilov also alludes to the German-Fascist zakhvatchiki of World War II and to the battle of Ukrainian peasants against those $z a k h v a t c h i k i^{43}$. Of course, the discussion of the Second World II itself by A. V. Mitrofanova and V. A. Zverev repeatedly refers to German-Fascist zakhvatchiki, Hitler's zakhvatchiki, German and Japanese zakhvatchiki, Fascist zavkhvatchiki, and just plain zakhvatchiki ${ }^{44}$. The chapter on culture by L. M.Zak mentions Fascist zakhvatchiki as well ${ }^{45}$.

\section{Zakhvatchiki in History}

Altogether over 40 authors employed the word zakhvatchiki in some form, 38 of whom I have named, one anonymous, and "one" a collective, almost a third of the contributors to the five-volume set. The use of the word was hardly an individual idiosyncracy. Although I have not tried to translate the narratives to a data base, I have compiled some suggestive statistics. The fields of history to which these specialists belong range from ancient to early modern to modern history, most of all modern. Counting eighteenth-century history as early modern, which seems to be the current trend, there was one reference to ancient history, 21 - to early modern history, and 42 - to modern history. Geographically, allusions to zakhvatchiki range from the Near East to all of Europe and Asia. In short, the term was applied to world history from its beginnings to recent times.

35 Shipaev V.I. Koreia // Ocherki istorii istoricheskoi nauki v SSSR. P. 795.

36 Nikiforov V.N. Kitai // Ibid. P. 812.

37 Podpalova G. I. Iaponiia // Ibid. P. 825.

38 Cherepnin L. V. Razvitie sovetskoi istoricheskoi nauki v pervoe poslevoennoe desiatiletie // Ibid. Vol.5. P. 19.

${ }^{39}$ Ivanova L. V. Institut marksizma-leninizma pri TsK KPSS // Ibid. P. 60.

40 Alatortseva A.I. Istoricheskaia periodika // Ibid. P.97-98.

${ }^{41}$ Emets V.A. Istoriografiia vneshnei politiki Rossii epokhi kapitalizma // Ibid. P. 362.

42 Maslov N. N. Razvitie istoriko-partiinoi nauki // Ibid. P. 379.

43 Danilov V. V. Izuchenie agrarnoi istorii sovetskogo obshchestva // Ibid. P.514, 515.

44 Mitrofanova A. V., Zverev V.A. Izuchenie istorii Velikoi Otechestvennoi voiny // Ibid. P. 524, 525, $544,545,546$.

${ }^{45}$ Zak L. M. Izuchenie istorii kul'turnogo stroitel'stva v SSSR // Ibid. P. 571. 
Tab. 1 reveals who was reviled as a zakhvatchik.

Table 1. Who was reviled as a zakhvatchiki

\begin{tabular}{|l|c|}
\hline \multicolumn{1}{|c|}{ Zakhvatchik } & Number of References \\
\hline Arabs & 1 \\
\hline Assyrians & 1 \\
\hline England & 6 \\
\hline France ${ }^{46}$ & 2 \\
\hline Germans & 11 \\
\hline Imperialists & 13 \\
\hline Iran and Persians & 4 \\
\hline Japan & 3 \\
\hline Ottomans & 2 \\
\hline Poland & 1 \\
\hline Romania ${ }^{47}$ & 2 \\
\hline Russia ${ }^{48}$ & 7 \\
\hline Swedes & 2 \\
\hline Tatars ${ }^{49}$ & 5 \\
\hline US & 2 \\
\hline Uzbeks & 2 \\
\hline Total & \\
\hline
\end{tabular}

The generic "imperialists" for the modern period presumably denotes English, French, Russian, American, and Japanese imperialists, but those entries counted just as "imperialists" omit any national identifications. Note that the category is not confined to Europeans.

The victims of zakhvatchiki are enumerated in Tab. 2.

Because in one instance "Russia and Eastern Europe" are the victims, there are 65 references in Table 2, one more than in Table 1. "World" denotes phraseology which just excoriated imperialist oppression world-wide. "Asia" and "Europe" are similar generalizations.

\footnotetext{
46 Including references to Napoleon as a zakhvatchik.

47 One each to Romanian boyars and the Romanian bourgeoisie.

48 Including references to the Russian government and bourgeoisie.

49 Both the Golden Horde and the Crimean Tatars.
} 
Table 2. Victims of Zakhvatchiki

\begin{tabular}{|l|c|}
\hline \multicolumn{1}{|c|}{ Victim } & Number of References \\
\hline Afghanistan & 2 \\
\hline Asia & 1 \\
\hline Balkans & $13^{50}$ \\
\hline Caucasus and North Caucasus & 6 \\
\hline Central Asia ${ }^{51}$ & 1 \\
\hline China & 1 \\
\hline Eastern Europe & 1 \\
\hline Egypt & 3 \\
\hline Estonia and Latvia & 1 \\
\hline Europe & 1 \\
\hline Georgia & 3 \\
\hline India & 3 \\
\hline Korea & 10 \\
\hline Ottomans & 2 \\
\hline Poland & 1 \\
\hline Russia & 3 \\
\hline Ukraine & 11 \\
\hline World & 10 \\
\hline
\end{tabular}

Some countries managed to be both zakhvatchiki and victims of zakhvatchiki. Poland was a victim of the Crimean Tatars but was a zakhvatchik at the beginning of the seventeenth century against Russia during the Time of Troubles. The Ottoman Empire was a zakhvatchik to Azerbaijan and elsewhere but the victim of European imperialist zakhvatchiki. One Iranian Shah repelled zakhvatchiki from Azerbaijan but another was the zakhvatchik in invading Armenian Nagorno-Karabakh. Although, to play devil's advocate, imperialists (and, among others, Tatars) never appear as the victims of zakhvatnichestvo, these examples of countries on both sides of the phenomenon suggest that the label zakhvatchik is situational, not primordial or essentialist.

\section{The Meaning of Zakhvatchiki}

No one-word translation adequately conveys the visceral emotional connotations of the word zakhvatchik. Suggested translations include: invader, aggressor, occupier, intruder,

${ }^{50}$ Including by name Armenia once, Georgia once, Azerbaijan six times.

${ }^{51}$ Including specific mention of Kazakhstan and Turkmenistan. 
encroacher, capturer, and pillager, to which I would add predator. Zakhvatchiki include those who launched slave raids and looting expeditions against a region and then left, and those who invaded to conquer and stayed. Zakhvatchiki exploit their victims either shortterm or long-term, but those classes who exploit their own societies and those governments who exploit their own subjects do not fall under the label of zakhvatchiki. Implicitly, the term denotes international exploitation, violent abuse of people other than those of the exploiter's country. Class oppression within a country does not constitute zakhvatnichestvo. The word "aggressor" captures the international element of the phenomenon, but creates semantic problems when dealing with a social class, not a country, and obscures the variety of aggressive means employed by zakhvatchiki.

Reading Soviet historiography on Rus'-Tatar relations induces the thought that the use of the word zakhvatchiki had an anti-nomadic coloration, but the evidence of Ocherki istorii istoricheskoi nauki $v$ SSSR conclusively establishes that such an interpretation ignores the broad spectrum of Soviet historical studies which used it in other times and places. Pastoral nomads, or societies that originated among pastoral nomads - Mongols, Ottomans, Uzbeks, to a degree Arabs - are described as zakhvatnicheskie, but they constitute a minority among zakhvatchiki in the five volumes of Ocherki istorii istoricheskoi nauki $v$ SSSR as a whole, most of whom had agricultural or later industrial economies and a sedentary way of life.

The classes, governments, and societies stigmatized by the pejorative zakhvatchiki have nothing in common except instances of aggressive behavior. They differ in ways of life, society, economy, form of government, and culture. From the point of view of Marxist theory, they have totally different systems of means of production, let alone superstructures. The medieval German crusader knights and bourgeois who invaded Estonia and Latvia did not have much affinity with contemporary medieval Mongols who created the largest land-locked empire in world history. The Polish szlachta who invaded Muscovy during the Time of Troubles do not resemble modern imperialists in their world-view. I do not see any value to historical knowledge in associating Mongols with Nazis. In short, the concept of zakhvatchiki is virtually a-historical. It does not depend upon any historical context other than some people, country or government acting badly toward some foreigner.

Therefore the word zakhvatchiki and its derivatives have no organic connection to Turkic peoples, nomads or Muslims, despite its prevalence in Soviet (and presence in post-Soviet) discourse about Rus'-Tatar relations. Soviet historians applied it to all times and all places, to anyone who used force to achieve goals that Soviet historians disapproved of. The proper translation might be "bad guys," although that is hardly within the acceptable register of historical discourse.

Soviet historians were selective in applying the term zakhvatchiki to Russia, as one would expect. The Russian government and Russian bourgeoisie were zakhvatchiki, but not the Russian "people." The word definitely fits fourteenth-century Novgorod ushkuini$k i$ looting their way down the Volga River and sixteenth-century Cossacks led by Ermak ravaging their way across western Siberia, but not in Ocherki istorii istoricheskoi nauki $v$ SSSR. Aleksandr Filiushkin labels Ivan IV's Livonian War as a "zakhvatnichestkaia war"52,

52 Filiushkin A. Andrei Kurbskii. Moscow, 2008. P. 101. 
but this is not a widespread opinion among historians in Russia specializing in Ivan IV's reign.

The word zakhvatchik does not appear in any medieval Rus' or early modern Russian source. It is by definition an anachronism. It is also, as I have tried to show, essentially a value judgment of who the "bad guy" is. It would be better if historians in Russia ceased using it at all. It must be conceded, however, that abandonment of applying the word zakhvatchiki to medieval Mongols and early modern Tatars will not in itself erase the anti-nomad bias of scholarship on the Mongols and the successor states of the Mongol Empire, which will continue to be a problem not only in Russian historiography on the Tatars and Rus'-Tatar relations, but in the world-wide field of Mongol studies.

\section{References}

Akatova A.I. Historiography of Turkmenistan. Ocherki istorii istoricheskoi nauki v SSSR. 1960, vol.2, pp. 798-807. (In Russian)

Akatova A. I., Kuliev O. K. Historiography of Turkmenistan. Ocherki istorii istoricheskoi nauki v SSSR. 1963, vol.3, pp.737-747. (In Russian)

Akhramovich R. T. Afghanistan. Ocherki istorii istoricheskoi nauki v SSSR. 1966, vol.4, pp. 763-768. (In Russian)

Alaev L. B. India. Ocherki istorii istoricheskoi nauki v SSSR. 1966, vol. 4, pp.775-786. (In Russian)

Alatortseva A.I. Historical Periodicals. Ocherki istorii istoricheskoi nauki v SSSR. 1985, vol.5, pp.91-109. (In Russian)

Alekseeva G.D., Gorodetskii E. N. Studying the History of the State and Economic Development of Russia. Ocherki istorii istoricheskoi nauki v SSSR. 1963, vol.3, pp. 189-200. (In Russian)

Alekseeva G. D., Gorodetskii E. N. Questions of General History in Bolshevik Literature. Ocherki istorii istoricheskoi nauki v SSSR. 1963, vol.3, pp. 201-211. (In Russian)

Alpatov M. A. Russian Medieval Studies. Ocherki istorii istoricheskoi nauki v SSSR. 1963, vol. 3, pp. 412-448. (In Russian)

Amel'kin A. O., Seleznev Yu. V. The Kulikovo Battle in the Testimonies of Contemporaries and the Memory of Descendants. Moscow, Kvadriga Publ., 2011, 684 p. (In Russian)

Cherepnin L. V. The Development of Soviet Historical Science in the First Post-War Decade. Ocherki istorii istoricheskoi nauki v SSSR, 1985, vol.5, pp. 12-23. (In Russian)

Danilov V.V. Studying the Agrarian History of Soviet Society. Ocherki istorii istoricheskoi nauki $v$ SSSR, 1985, vol.5, pp. 491-520. (In Russian)

Danilova L. V. Introduction. Ocherki istorii istoricheskoi nauki v SSSR, 1966, vol. 4, pp. 732-744. (In Russian)

Draudin T. Ya. Historiography of Latvia. Ocherki istorii istoricheskoi nauki v SSSR, 1960, vol. 2, pp.733-745. (In Russian)

Fadeev A. V. Russian Foreign Policy in Coverage of Soviet Historians. Ocherki istorii istoricheskoi nauki v SSSR, 1966, vol. 4, pp. 427-440. (In Russian)

Filiushkin A. Andrei Kurbskii. Moscow, Molodaia Gvardiia Publ., 2008, 298 p. (In Russian)

Emets V.A. Historiography of the Foreign Policy of Russia in the Era of Capitalism. Ocherki istorii istoricheskoi nauki v SSSR, 1985, vol. 5, pp. 358-369. (In Russian)

Gasanov I. M., Guliev A.N. Historiography of Azerbaijan. Ocherki istorii istoricheskoi nauki v SSSR, 1960, vol. 2, pp. 771-789. (In Russian)

Gimadi Kh. K. Historiography of Tatarstan. Ocherki istorii istoricheskoi nauki v SSSR, 1960, vol.2, pp. 820825. (In Russian)

Grosul Ia.S., Mokhov N. A. Historiography of Moldova. Ocherki istorii istoricheskoi nauki v SSSR, 1960, vol. 2, pp. 745-751. (In Russian)

Guliev A. N., Gasanov I. M., Strigunov I. V. Historiography of Azerbaijan. Ocherki istorii istoricheskoi nauki $v$ SSSR, vol.3, pp. 715-726. (In Russian)

Halperin C. J. Yu. V. Seleznev's Contribution to the Study of the Juchid ulus. Zolotoordynskoe obozrenie, 2014, vol. 2, no. 4, pp. 74-94.

Iansen E. A. Historiography (Estonia) in the Period of Capitalism. Ocherki istorii istoricheskoi nauki v SSSR, 1963, vol.3, pp.682-686. (In Russian) 
Ivanova L. V. Institute of Marxism-Leninism under the Central Committee of the CPSU. Ocherki istorii istoricheskoi nauki v SSSR, 1985, vol. 5, pp.59-71. (In Russian)

Illeritskii V.E. The Main Features of the Development of Historical Knowledge of the 30-50s of the $20^{\text {th }}$ Century. Ocherki istorii istoricheskoi nauki v SSSR, 1955, vol. 1, pp.311-317. (In Russian)

Illeritskii V.E. Historical Views of A.I.Herzen. Ocherki istorii istoricheskoi nauki v SSSR, 1955, vol.1, pp. 386-414. (In Russian)

Khakimov R. Foreword. The Golden Horde in World History. A Multi-Authored Monograph. Kazan', 2017, pp.3-4.

Kovalenko L. A. Historiography of Ukraine. Ocherki istorii istoricheskoi nauki v SSSR, 1955, vol. 1, pp. 599611. (In Russian)

Laigna K. Historiography of Estonia. Ocherki istorii istoricheskoi nauki v SSSR, 1955, vol. 1, pp.622-625. (In Russian)

Maslov N.N. The Development of Party History. Ocherki istorii istoricheskoi nauki v SSSR, 1985, vol.5, pp. 370-393. (In Russian)

Mitrofanova A. V., Zverev V.A. Studying the History of the Great Patriotic War. Ocherki istorii istoricheskoi nauki v SSSR, 1985, vol. 5, pp. 521-527. (In Russian)

Nabiev R. N. Historiography of Uzbekistan. Ocherki istorii istoricheskoi nauki v SSSR, 1955, vol. 1, pp. 160165. (In Russian)

Nepomnin V.Ya. Historiography of Uzbekistan. Ocherki istorii istoricheskoi nauki v SSSR, 1963, vol.3, pp.727-737. (In Russian)

Nikiforov V.N. China. Ocherki istorii istoricheskoi nauki v SSSR, 1966, vol.4, pp. 800-817. (In Russian)

Nikitin S. A. Slavic Studies. Ocherki istorii istoricheskoi nauki v SSSR, 1963, vol.3, pp. 498-514. (In Russian)

Podpalova G. I. Japan. Ocherki istorii istoricheskoi nauki v SSSR, 1966, vol. 4, pp. 817-826. (In Russian)

Rudakov V.N. Mongol-Tatars Through the Eyes of the Ancient Russian Scribes of the Middle of the $13^{\text {th }}-15^{\text {th }}$ Centuries. Moscow, Kvadriga Publ., 2009, 248 p. (In Russian)

Seleznev Yu. V. Pictures of the Horde Yoke. Voronezh, Voronezh Gosudarstvennyi Universitet Press, 2017, 437 p. (In Russian)

Seleznev Yu. V. Russian-Horde Conflicts of the 13 ${ }^{\text {th }}$-15th Centuries. Moscow, Kvadriga Publ., 2010, 224 pp. (In Russian)

Shipaev V.I. Korea. Ocherki istorii istoricheskoi nauki v SSSR, 1966, vol. 4, pp. 793-800. (In Russian)

Smirnov N. A. Studying the History of the Countries of the Near and Middle East. Ocherki istorii istoricheskoi nauki v SSSR, 1960, vol. 2, pp.526-533. (In Russian)

Smirnov N. A. Exploring the Near and Middle East. Ocherki istorii istoricheskoi nauki v SSSR, 1963, vol.3, pp. 536-547. (In Russian)

Smirnov N. A. Turkey. Ocherki istorii istoricheskoi nauki v SSSR, 1966, vol. 4, pp. 744-753. (In Russian)

Trepavlov V. Introduction. The Golden Horde in World History. A Multi-Authored Monograph, Kazan', 2017, pp. $7-12$.

Zak L. M. Studying the History of Cultural Construction in the USSR. Ocherki istorii istoricheskoi nauki v SSSR, 1985, vol. 5, pp.568-587. (In Russian)

Zimin A. A., Preobrazhenskii A. A. Studying the history of feudalism in Russia. Ocherki istorii istoricheskoi nauki v SSSR, 1966, vol.4, pp. 271-308. (In Russian)

Received: May 26, 2019

Accepted: September 9, 2019

Статья поступила в редакцию 26 мая 2019 г.

Рекомендована в печать 9 сентября 2019 г. 